\title{
Tumor-specific donor lymphocyte infusion therapy with allogeneic $T$ cells utilizing novel retrovirus vector silencing endogenous TCR expression
}

\author{
Hiroaki Ikeda ${ }^{*}$, Hiroaki Ueno ${ }^{1}$, Ayumi Kawamura², Naoko Imai ${ }^{3}$, Sachiko Okamoto², Junichi Mineno², \\ Kazutoh Takesako², Hiroshi Shiku' \\ From Society for Immunotherapy of Cancer 29th Annual Meeting \\ National Harbor, MD, USA. 6-9 November 2014
}

\section{Background}

Donor Lymphocyte infusion (DLI) is a therapy for the patients with relapsed hematological malignancy after allogeneic hematopoetic stem cell transplantation. However, the development of Graft-Versus-Host Disease (GVHD) is a serious adverse event and the efficacy is limited when one needs to control the GVHD. To inhibit the development of GVHD with increased tumor-specificity of transferred allogeneic lymphocytes, here we demonstrate the development of DLI with lymphocytes engineered to express tumor-specific $\mathrm{T}$ cell receptor (TCR) in combination with decreased GVHD-inducing potential utilizing the novel retrovirus vector (siTCR vector) that specifically silences endogenous TCR in gene-engineered T cells.

\section{Methods}

Human PBMC were transduced with a high affinity TCR specific to a cancer/testis antigen, NY-ESO-1, by the retrovirus vector with siRNA specific to the endogenous TCR. Resulting TCR gene-transduced T cells were examined for their reactivity to allogeneic LCL by ${ }^{3} \mathrm{H}$ uptake proliferation assay. Immunodeficient NOG mice were inoculated with a NY-ESO-1-expressing human melanoma cell line NW-MEL-38, received TCR gene-transduced T cells, and monitored for tumor growth and the development of GVHD.

\section{Results}

Human lymphocytes that were genetically engineered to express a high affinity NY-ESO-1-specific TCR with siTCR vector showed reduced expression of endogenous
TCR associated with the dramatically diminished reactivity to allogeneic lymphocytes. When administrated into NOG mice, these TCR gene-transduced T cells induced tumor regression without the development of GVHD.

\section{Conclusions}

The results here suggest that the allogeneic $\mathrm{T}$ cells transduced with a tumor-specific TCR by siTCR vector showed diminished GVHD potential. These T cells will be applicable to the donor lymphocytes infusion therapy after allogeneic stem cell transplantation for the treatment of hematological malignancy, providing diminished GVHD and increased tumor eradication.

\section{Authors' details \\ ${ }^{1}$ Mie University Graduate School of medicine, Department of Immuno-Gene Therapy, Tsu, Japan. ${ }^{2}$ Takara Bio Inc., Otsu, Japan. ${ }^{3}$ Department of Medicine, Division of Hematology/Oncology, The Tisch Cancer Institute at Hess Center for Science and Medicine,Icahn School of Medicine at Mt. Sinai, Japan.}

Published: 6 November 2014

doi:10.1186/2051-1426-2-S3-P20

Cite this article as: Ikeda et al:: Tumor-specific donor lymphocyte infusion therapy with allogeneic T cells utilizing novel retrovirus vector silencing endogenous TCR expression. Journal for ImmunoTherapy of Cancer 2014 2(Suppl 3):P20.

${ }^{1}$ Mie University Graduate School of medicine, Department of Immuno-Gene

Therapy, Tsu, Japan

Full list of author information is available at the end of the article

(c) 2014 Ikeda et al.; licensee BioMed Central Ltd. This is an Open Access article distributed under the terms of the Creative Commons Attribution License (http://creativecommons.org/licenses/by/4.0), which permits unrestricted use, distribution, and reproduction in any medium, provided the original work is properly cited. The Creative Commons Public Domain Dedication waiver (http:// creativecommons.org/publicdomain/zero/1.0/) applies to the data made available in this article, unless otherwise stated. 